\title{
Drought stress and changes in the lignin content and composition in Eucalyptus
}

\author{
Jullyana Moura-Sobczak, Uiara Souza ${ }^{*}$, Paulo Mazzafera \\ From IUFRO Tree Biotechnology Conference 2011: From Genomes to Integration and Delivery \\ Arraial d'Ajuda, Bahia, Brazil. 26 June - 2 July 2011
}

It is known that many abiotic stresses, such as mineral deficiency, drought, UV-B radiation, wind and low temperatures, alter the quantity and composition of lignin in several species [1]. The aim of this work was to verify if the drought stress may cause changes in the quantity and composition of lignin in Eucalyptus globulus Labill and in the hybrids $E$. urograndis (E. urophylla $\times$ E. grandis) and E. uroglobulus (E. globulus $x$ E. urograndis). In the experiments the plants were divided in three groups (control, drought and drought recovered.) The control plants were irrigated daily. The plants from the group "drought" were not irrigated and were collected when wilt symptom was observed. The plants from the group "drought recovered" were irrigated when wilt was observed and were collected after recovery.

Samples of basal and apical regions of the stem were collected and analyzed for total lignin with thioglycolic acid [2] and analyzed by GC-MS to determine lignin monomeric composition [3].

E. urograndis subjected to drought decreased the amount of lignin in the stem apical regions and increased lignin in the basal region. E. globulus showed opposite behavior in apical regions and showed no significant changes in the basal regions. E. uroglobulus showed a pattern similar to E. urograndis in apical regions and similar to E. globulus in basal regions.

Although E. urograndis and E. uroglobulus reduced lignin and E. globulus increased in the apical part of the stem, it was observed that these different adjustments of lignin deposition eventually result in an increased proportion of S/G in both species. Moreover, when the amount of lignin is increased in the basal regions of E. urograndis there is a decrease in the proportion $\mathrm{S} / \mathrm{G}$.

\footnotetext{
* Correspondence: uiarakrs@yahoo.com.br
1. Departamento de Fisiologia Vegetal. Instituto de Biologia - Unicamp. CEP:

* Correspondence: uiarakrs@yahoo.com.br
1. Departamento de Fisiologia Vegetal. Instituto de Biologia - Unicamp. CEP: 13083-970 Campinas, SP, Brazil
}

Increasing the proportion $\mathrm{S} / \mathrm{G}$, either by increasing the amount of lignin-rich syringyl units or reduction of coniferyl units can be an important aspect in the adaptation of both species to drought stress.

Published: 13 September 2011

\section{References}

1. Moura JCMS, Bonine CAV, Viana JOF, Dornelas MC, Mazzafera P: Abiotic and Biotic Stresses and Changes in the Lignin Content and Composition in Plants. J Integr Plant Biol 2010, 52(4):360-376.

2. Lange BM, Lapierre C, Sandermann HJR: Elicitor-induced spruce stress lignin. Plant Physiol 1995, 108:1277-1287.

3. Rolando C, Monties B, Lapierre C: Thioacidolysis. In Methods in Lignin Chemistry. Berlin: Springer-Verlag;Lin S, Dence C 1992:334-349.

doi:10.1186/1753-6561-5-S7-P103

Cite this article as: Moura-Sobczak et al:: Drought stress and changes in the lignin content and composition in Eucalyptus. BMC Proceedings 2011 5(Suppl 7):P103.

Submit your next manuscript to BioMed Central and take full advantage of:

- Convenient online submission

- Thorough peer review

- No space constraints or color figure charges

- Immediate publication on acceptance

- Inclusion in PubMed, CAS, Scopus and Google Scholar

- Research which is freely available for redistribution 